\title{
Voorstelle vir die produksie van 'n vertaalwoordeboek vir professionele vertalers*
}

\author{
M.F. Crafford (riacrafford@adept.co.za) en Ilse Feinauer (aef@sun.ac.za) \\ Departement Afrikaans en Nederlands, Universiteit van Stellenbosch, \\ Stellenbosch, Republiek van Suid-Afrika
}

Opsomming: Die profiel van die potensiële gebruiker moet die riglyn wees by alle leksikografiese besluite telkens wanneer woordeboeke beplan, hersien of saamgestel word. Die formaat, struktuur en ordening van 'n vertaalwoordeboek gerig op professionele vertalers behoort gevolglik dus op die spesifieke behoeftes van hierdie bepaalde gebruikersgroep gebaseer te wees. Hierdie artikel bevat algemene riglyne vir die hantering van altwee die buitetekste en die sentrale lys van 'n vertaalwoordeboek gerig op die behoeftes van beroepsvertalers wat hoofsaaklik uit Engels (T2) in Afrikaans (T1) vertaal. 'n Moontlike formaat vir die mikrostruktuur van so 'n woordeboek (Engels $>$ Afrikaans) word gegee en die moontlike leksikografiese bewerking van ' $n$ aantal voorbeeldlemmas word in besonderhede bespreek. Die moontlikheid van formatiewe evaluering met behulp van die beginsel van gelyktydige terugvoer word kortliks aangeraak.

Sleutelwoorde: WOORDEBOEKPRODUKSIE, VERTAALWOORDEBOEK, WOORDEBOEKINSKRYWINGS, WOORDEBOEKFUNKSIES, LEKSIKOGRAFIESE ETIKETTE, GELYKTYDIGE TERUGVOER, WOORDEBOEKKORPUS, MAKROSTRUKTUUR, MIKROSTRUKTUUR

\begin{abstract}
Suggestions for the Production of a Translation Dictionary for Professional Translators. The profile of the potential user needs to be the guiding principle in all lexicographic decisions whenever dictionaries are designed, revised or compiled. It follows, then, that the format, structure and organisation of a translation dictionary aimed at the needs of professional translators should be based on the specific needs of that distinct user group. This article contains general guidelines for both the outer texts and the central part of a translation dictionary aimed at the needs of professional translators mainly translating from English (T2) into Afrikaans (T1). A possible format for the microstructure of such a dictionary (English $>$ Afrikaans) is given and the possible lexicographic treatment of a few sample entries is discussed in detail. The possibility of formative evaluation by means of the principle of simultaneous feedback is briefly touched on.
\end{abstract}

Keywords: DICTIONARY PRODUCTION, TRANSLATION DICTIONARY, DICTIONARY ENTRIES, DICTIONARY FUNCTIONS, LEXICOGRAPHIC LABELLING, SIMULTANEOUS FEEDBACK, DICTIONARY CORPUS, MACROSTRUCTURE, MICROSTRUCTURE

* Hierdie artikel is gebaseer op 'n M.Phil.-skripsie Vertalers en hul bronne: Die behoefte aan ' $n$ vertaalwoordeboek met Engels en Afrikaans as behandelde taalpaar wat in 2005 onder leiding van prof. A.E. Feinauer aan die Universiteit van Stellenbosch, Stellenbosch, Republiek van SuidAfrika, voltooi is. 


\section{Inleiding}

Roberts (1990: 92) wys op die gebrek aan gepubliseerde materiaal met betrekking tot 'n metodologie van woordeboekproduksie. Sy meen dis onder meer omdat nuwe woordeboeke dikwels uit voriges ontwikkel. Hulle ontstaan sodoende op grond van veranderings wat aan hul voorgangers gemaak word. As direkteur van die Bilingual Canadian Dictionary (BCD) Project, ${ }^{1}$ is Roberts (1996: 16-21) wel in staat om op grond van haar eie ervaring van woordeboekmaak bepaalde stappe in die beplanningsproses te beskryf wat belangrik is wanneer 'n nuwe woordeboek beslag moet kry. Die stappe wat sy uiteensit, dui op belangrike besluite wat oor verskeie aspekte van 'n nuwe woordeboek geneem moet word. Gaan dit byvoorbeeld slegs in gedrukte vorm of ook elektronies beskikbaar gestel word? Louw (1999: 108) beklemtoon dat die sukses van woordeboeke afhang van die toeganklikheid van hul makro- en mikrostrukturele inligting. Hy toon hoedat elektroniese woordeboeke geleenthede vir die implementering van gidsstrukture skep wat nie in gedrukte weergawes moontlik is nie. In die lig hiervan is dit gewens dat 'n vertaalwoordeboek ook in 'n elektroniese weergawe verskyn - ' $n$ besluit wat by vertalers byval behoort te vind.

Navorsing oor die vertaalproses en die werkwyse en eienskappe van professionele vertalers toon dat dié groep potensiële woordeboekgebruikers eiesoortige behoeftes het wat nie noodwendig optimaal deur tweetalige woordeboeke, soos hulle tradisioneel daar uitsien, bevredig word nie (Crafford 2005). Omdat die belangrikste uitgangspunt by die beplanning, hersiening of samestelling van woordeboeke die potensiële woordeboekgebruiker moet wees, moet professionele vertalers se behoeftes die grondslag vorm vir alle besluite oor die formaat, struktuur en ordening van 'n vertaalwoordeboek vir dié gebruikersgroep. Meer nog, professionele vertalers behoort deel te wees van die span leksikograwe wat aan so 'n vertaalwoordeboek werk.

'n Belangrike eerste stap is dat die span leksikograwe oor die algemene aard van die beoogde woordeboek duidelikheid kry. Vir die doeleindes van hierdie artikel word gekonsentreer op 'n vertaalwoordeboek wat primêr op die behoeftes van professionele vertalers uit Engels (T2) in Afrikaans (T1) werk. Die potensiële gebruikers van so 'n vertaalwoordeboek in Engels en Afrikaans is 'n gesofistikeerde gebruikersgroep wat oor 'n goeie kennis van sowel hul tweede as hul eerste taal beskik en meer inligting benodig as wat in gewone tweetalige woordeboeke gegee word. Die Engels-Afrikaans-vertaalwoordeboek behoort 'n algemene woordeboek te wees "[which] will also include a fairly high proportion of terms in a number of fields, as well as word combinations such as collocations and fixed expressions often found in special-purpose dictionaries" (Roberts 1996: 17). Beperkinge ten opsigte van die omvang van die woordeboek moet in ag geneem word. Hoe meer inligting, hoe dikker die woordeboek.

In aansluiting by die verskillende kenmerke waaroor ' $n$ vertaalwoorde- 
boek ideaal gesproke moet beskik (Crafford 2005), word vervolgens aan die hantering van die voortekste-afdeling, sentrale lys en agtertekste-afdeling aandag gegee. Hedendaagse woordeboeke wat "draers van tekssoorte" is, gebruik die sogenaamde raamstruktuur om die verskillende datatipes in 'n woordeboek te akkommodeer (Gouws 2001: 81). Deeglike beplanning is nodig vir die strukturering en inhoud van sowel die sentrale lys as die buitetekste. Die buitetekste wat nie net tot beter inligtingsontsluiting vir die woordeboekgebruiker bydra nie, maar ook 'n rol in die dataverspreidingstruktuur van die woordeboek speel (Keyser 2003: 35-36), moet as deel van die omvattende leksikografiese proses aandag kry.

\section{Die voortekste-afdeling}

Die voortekste-afdeling van ' $n$ vertaalwoordeboek sal uit elemente soos die volgende bestaan:

- $\quad$ 'n Voorwoord wat onder meer aandui waarom en vir wie die woordeboek saamgestel is, waarom bepaalde besluite geneem is en watter metodes die samestellers gevolg het.

- Verklarende aantekeninge wat verduidelik hoe gebruikers woorde en uitdrukkings kan vind waarna hulle soek, wat die redaksionele afkortings beteken, hoe verskille in spelling of betekenis tussen Britse en Amerikaanse Engels aangedui word, en hoe die inligting georden is.

- $\quad$ 'n Gebruikersgids wat die toegang-, artikel- en mediostruktuur van die woordeboek uiteensit en verduidelik watter struktuurmerkers gebruik word.

- 'n Afdeling waarin leksikografiese gebruike verduidelik word, soos gebruiksetikette, kruisverwysings, lettergreepverdeling en uitspraakleiding.

Die beoogde gebruiker en die funksie(s) van die woordeboek bepaal in watter taal die inligting in die buitetekste gegee word. In 'n Engels-Afrikaans-vertaalwoordeboek sal die inligting in die doeltaal wees, m.a.w. in Afrikaans.

\section{Die sentrale lys}

Die sentrale lys van die beoogde Engels-Afrikaans-vertaalwoordeboek sal uit die artikelreekse van A-Z saamgestel wees. ${ }^{2}$ Elke woordeboekartikel bestaan uit 'n lemma as die vernaamste bewerkingseenheid en inskrywings wat deel van die bewerking daarvan uitmaak.

Belangrike besluite wat die leksikografiese span moet neem, handel oor die makrostruktuur (die versameling lemmas). Watter leksikale items moet in 
'n vertaalwoordeboek opgeneem word? Tradisioneel kopieer leksikograwe in 'n groot mate die leksikale elemente van soortgelyke woordeboeke, maar Tarp (2004: 314) maan dat geen data ingesluit moet word omdat dit nog altyd so gedoen is of omdat ander bestaande woordeboeke dit het nie. Tog meen Roberts (1996: 18) dis 'n aanvaarbare punt om by te begin, maar dat alle finale besluite op die ontleding van geskikte korpusse gegrond moet word.

Tegnologiese ontwikkelings van die afgelope jare maak dit vir die eerste keer moontlik om op groot skaal verteenwoordigende elektroniese korpusse te bekom en tipiese patrone van werklike taalgebruik daarin te ontleed. Hierdie inligting kan sodoende die onderbou van woordeboeke vorm. Die BCD-projek het teen 1996 reeds 'n korpus van nagenoeg 310 miljoen woorde opgebou (Roberts 1996: 18); die COBUILD-argief bevat sowat 500 miljoen woorde (Sinclair et al. 1997: ix).

Die wesenskenmerke van ' $n$ korpusgedrewe benadering is volgens Biber et al. (1998: 4) dat dit

- empiries is en werklike gebruikspatrone in natuurlike (outentieke) tekste ontleed;

- $\quad$ 'n groot versameling natuurlike tekste (die korpus) volgens bepaalde beginsels en metodes vir ontleding selekteer;

- die ontleding op die omvattende gebruik van rekenaars asook outomatiese sowel as interaktiewe tegnieke baseer (m.a.w. die leksikograaf kan in probleemgevalle sy/haar eie linguistiese oordeel gebruik); en

- sowel kwantitatiewe as kwalitatiewe ontledingstegnieke aanwend.

'n Korpusgedrewe benadering lei tot leksikografiese produkte wat verteenwoordigend en gebalanseerd is. Simpson (2002: 9) meen: "Nowadays, it would be a brave lexicographer who did not at least associate his or her dictionary with a corpus, however comprehensively that corpus was actually used to extract lexical information."

Biber et al. (1998: 23-24) se korpusgedrewe leksikografiese navorsing stel veral na ses belangrike vrae ondersoek in:

- Watter betekenisse word met 'n bepaalde woord geassosieer?

- Hoe dikwels word ' $n$ bepaalde woord relatief tot ander verwante woorde gebruik?

- Met watter nielinguistiese patrone (bv. registers, tydperke in die geskiedenis, streektaal) word 'n bepaalde woord geassosieer?

- Watter ander woorde word algemeen saam met 'n bepaalde woord gebruik, en hoe lyk die verspreiding van hierdie kollokasionele verbindings ("collocational sequences") oor verskillende registers heen? 
- Hoe lyk die verspreiding van betekenisonderskeidings en gebruikstoepassings ("senses and uses") van 'n woord?

- Hoe verskil die gebruik en verspreiding van woorde wat skynbaar sinonieme is?

By die gebruik van Afrikaanse korpusse om "tipiese patrone van werklike taalgebruik" vas te stel, is 'n belangrike vraag of leksikograwe beskrywend of voorskrywend te werk moet gaan. Feinauer (2001: 165) wys op die "massiewe" invloed wat Engels toenemend op Afrikaans het weens die oorheersende rol wat Engels daagliks in die ervaringswêreld van elke individu speel. Dit bring tot so ' $n$ mate ' $n$ konseptuele verandering mee in die leksikalisering van konsepte in Afrikaans deur moedertaalsprekers, dat die taalgebruik in sommige van die voorste Afrikaanse koerante en radio- en televisieprogramme deurspek raak van leenvertalings en geleende taalvorme. "The original Afrikaans conceptualized form seems alien, too formal and prosaic to the everyday user of Afrikaans" (Feinauer 2001: 166). By die uitsoek van Afrikaanse korpusse en die selektering en ordening van leksikale materiaal moet hierdie tendens oorweging geniet.

Ten opsigte van die makrostruktuur en die dataverspreidingstruktuur is 'n belangrike besluit watter elemente hooflemmastatus moet kry. Afkortings? Morfeme? Akronieme? Gaan kollokasies en idiome aparte inskrywings wees of nis- en neslemmas vorm? Watter multileksikale items gaan as hooflemmas opgeneem word?

Nadat die span leksikograwe besluit het watter leksikonelemente in die vertaalwoordeboek opgeneem behoort te word, besluit hulle watter inligting oor elk van die lemmas verstrek gaan word. Hierdie bewerking van die lemmas verteenwoordig die mikrostruktuur, oftewel die interne struktuur van elke artikel. Hieraan word in meer besonderhede in paragrawe 5 en 6 hieronder aandag geskenk.

\section{Die agtertekste-afdeling}

Elemente wat vir opname in die agtertekste-afdeling van die voorgestelde vertaalwoordeboek oorweeg kan word, is die volgende:

- Omrekeningstabelle vir mate (lengte, oppervlak, volume, e.s.m.), gewigte en temperatuur ten einde voorsiening te maak vir verskille in Amerikaanse, Britse en Suid-Afrikaanse gebruike. (Die rede waarom hierdie soort inligting vir die vertaler in Afrikaans van nut kan wees, is omdat outeurs - bv. dosente wat lesingmateriaal voorberei met behulp van Amerikaanse of Britse handboeke - nie altyd vir hul Suid-Afrikaanse lesers die nodige aanpassings maak nie sodat die vertaler dit dan moet doen.) 
- Kultuurgebonde data.

- Plekname asook beginsels vir die transliterasie van plekname in Afrikaans.

- Besonderhede van hulpbronne en kontakte wat vir vertalers nuttig kan wees, byvoorbeeld die name en/of internetadresse van organisasies en verenigings soos die Suid-Afrikaanse Vertalersinstituut, die English Academy of Southern Africa, die Departement van Justisie se Regsbiblioteek vir die name van wette, die Departement van Kuns en Kultuur se Nasionale Taal- en Terminologiediens, universiteite se vertaal- of taalskole, e.s.m.

- $\quad$ 'n Ekwivalentregister wat die woordeboek politoeganklik kan maak. (Omdat dit die gebruiksbestek van die woordeboek verhoog, kan dit 'n baie nuttige buiteteks wees.)

\section{5. 'n Voorgestelde formaat vir die mikrostruktuur van 'n vertaalwoorde- boek}

Die voorgestelde formaat vir die bewerking van ' $\mathrm{n}$ aantal voorbeeldlemmas hieronder is naastenby op die formaat geskoei wat die BCD-projek gebruik (Roberts 1992a, Roberts 1992b, Roberts 1996 en die webwerf http://www.dico. uottawa.ca/entries-en.htm). Dis 'n tentatiewe formaat - die praktyk sal verdere verfyning vereis - wat soos volg daar uitsien: ${ }^{3}$

\section{Inleidende afdeling}

trefwoord met lettergreepindeling $>$ woordsoort $>$ fonetiese transkripsie $>$ (spelvariant) $>$ (verbuiging van werkwoorde)

\section{Betekenisafdeling}

(nommer van betekenisonderskeiding $)>($ leksikografiese etiket BT) $>$ parafrase BT > parafrase/ekwivalente/sinonieme DT > (leksikografiese etiket DT) > voorbeeldmateriaal/vrye woordverbindings BT + DT > (kollokasies BT + DT)

(brontaalsinonieme $)^{4}$ (kruisverwysings) $>$ (brontaalantonieme)

(Afdeling vir vaste uitdrukkings)

(uitdr) $(\mathrm{BT}+\mathrm{DT})>$ (kruisverwysing)

Afdeling vir samestellings

(ss) $>($ BT + DT $)>($ kruisverwysing $)$

(Die elemente tussen hakies verskyn nie noodwendig in elke artikel nie.)

Die voorbeeld wat die BCD bied, word om verskeie redes nuttig en relevant geag by die saamstel van 'n vertaalwoordeboek in Engels en Afrikaans: 
- Dis 'n uitgesproke doelstelling van die BCD-projek om 'n woordeboek vir gesofistikeerde taalgebruikers, byvoorbeeld professionele vertalers, te ontwerp. Roberts, direkteur van die projek, is self 'n ervare professionele vertaler wat met ontwikkelings in vertaalstudie tred hou.

- Kanada is amptelik tweetalig en die taalwerkers in Frans en Engels het dieselfde gevorderde vlak van tweedetaalbeheer as taalwerkers in Afrikaans en Engels. Dit het direk betrekking op hul potensiële woordeboekgebruik.

- Gesofistikeerde woordeboekgebruikers het meer as basiese vertaalekwivalente nodig. Om daardie rede bevat die BCD meer inligting, en meer gegewens oor daardie inligting, as die meeste enkelvolumewoordeboeke: tegniese terme, multileksikale items (samestellings, vaste uitdrukkings en kollokasies), soveel doeltaalekwivalente as moontlik, betekenisaanduiding by brontaallemmas, betekenisonderskeidings vir doeltaalekwivalente, verskillende voorbeelde van vrye verbindings wat die lemma kan vorm en verskeie moontlike vertalings daarvan (Roberts 1992a: 219).

- Die BCD dien as 'n voorbeeld van hoe al dié materiaal georden kan word sodat besige taalpraktisyns, soos vertalers wat gewoonlik onder tyddruk werk, dit vinnig en maklik kan naslaan.

- Die BCD gee die betekenisverklaring van lemmas in die brontaal. Navorsing oor die tussentalige vermoëns van vertalers (Presas 2000: 21-26) toon dat dit 'n gekoördineerde tweetalige taalgeheue bevorder, waaroor professionele vertalers ideaal gesproke moet beskik, en ook die vertaler se skeppende vermoë tot diens kan wees (Kussmaul 1995: 51).

- Die baanbrekerswerk van die BCD is goed gedokumenteer en die metodes wat die samestellers gevolg het, is daarom vir ander woordeboeksamestellers toeganklik.

'n Voorbeeld van hoe die BCD trefwoorde hanteer, werp lig op die struktuur waarvolgens dié woordeboek inligting bewerk en aanbied (Bilingual Canadian Dictionary: Sample Entries 2004):

car pool $n$ or carpool or car-pool

1 (arrangement whereby several commuters travel together in one car and share costs) covoiturage $m$. *I commute to work by car pool je fais du covoiturage pour aller au travail.

2 (group of commuters travelling together in such an arrangement) groupe de covoiturage $m$. *to belong to a car pool faire partie d'un groupe de covoiturage.

3 (number of cars owned by a company or organization for the use of its members) parc automobile $m$.

(cmp1) car pool lane $n$ voie réservée au covoiturage $n f$; car pool lot $n$ stationnement réservé aux covoitureurs $n m[(C D)]$.

carpool vi or car pool or car-pool

1 (to travel with other commuters in one car and share costs) faire du covoiturage, 
covoiturer $[(C D)]$. *seven of us carpool to work nous sommes sept à faire du covoiturage pour aller au travail = nous sommes sept à covoiturer pour aller au travail.

\begin{abstract}
carpool $v t$ or car pool or car-pool
1 (to take turns driving passengers somewhere) expl.: conduire des passagers quelque part. *it is my turn to carpool the neighbourhood's kids to school this week c'est à mon tour de conduire les enfants du voisinage à l'école cette semaine.

car pooler $n$ or carpooler or car-pooler

1 (member of a group of commuters who travel together in one car and share costs) covoitureur $\mathrm{m}[(C D)], f$ covoitureuse $[(C D)] .{ }^{*}$ car poolers are allowed to park here all day il est permis aux covoitureurs de stationner ici toute la journée.

car pooling $n$ or car-pooling or carpooling

1 (transportation in a private vehicle of several passengers who share operating costs) covoiturage $m$. *car pooling reduces traffic congestion and air pollution le covoiturage réduit les embouteillages et la pollution de l'air.
\end{abstract}

By die konstruksie hieronder van woordeboekinligting vir die voorgestelde Engels-Afrikaans-vertaalwoordeboek is dimensies bygevoeg wat die BCD nie het nie. Eerstens word die lettergreepindeling en verbuigde vorme van die lemma aangetoon, omdat dit by die versorging van dokumente vir taalwerkers belangrik is. Tweedens word sinonieme van die lemma waar moontlik gelys, omdat dit ingevolge beskrywings van die vertaalproses (sien veral Presas 2000: 21-25; Neubert en Shreve 1992: 43-46; Mossop 1998: 40; Kussmaul 1995: 40-51; Tarp 2002: 73 en Crafford 2005: 56-59) kan meehelp dat die vertaler 'n gepaste vertaling maak. Die brontaalsinonieme ondersteun twee kommunikasiegerigte leksikografiese funksies van die vertaalwoordeboek, te wete om vertalers met die begrip van tekste in hul tweede taal en die vertaling van tekste uit hul tweede taal in hul eerste taal te help.

Die leksikale items wat hieronder bespreek word, is só gekies dat die voorgestelde formaat met betrekking tot verskeie sake getoets kan word. Die bewerking van die leksikale items neem van paragraaf 6.1 tot 6.2 in kompleksiteit toe. Eerste aan die beurt is 'n leksikale item (incur) met 'n enkele woordsoortelike funksie en slegs een betekenisonderskeiding, maar wat 'n aantal kollokasionele verbindings kan vorm. Daarna volg 'n leksikale item (endeavour) met meer as een woordsoortelike funksie, maar slegs een betekenisonderskeiding vir elke funksie. Dié item illustreer die hantering van 'n wisselvorm wat spelwyse betref, die gebruik van leksikografiese etikette, die optrede van die item in ' $n$ vaste kombinasie met ' $n$ voorsetsel, 'n samestelling waar die eerste element nie die lemma is nie, en 'n kruisverwysing. Die volgende leksikale item (juggle) is veral gekies omdat Afrikaanssprekendes die Engelse woord dikwels net so leen. Dié item illustreer onder meer die gebruik van leksikografiese etikette en die hantering van 'n vaste uitdrukking.

Hierna kom twee multileksikale leksikale items aan die beurt. Die eerste (die lemma big bang theory) is 'n leksikale item wat net een woordsoortelike funksie het en wat die gebruik van 'n leksikografiese etiket en die aanbied van ensiklopediese inligting toon. Die multileksikale leksikale item fast track het meer as een woordsoortelike funksie en toon die hantering van ' $n$ wisselende 
spelvorm by funksiewisseling, asook die hantering van 'n idiomatiese uitdrukking.

Die volgende woordeboeke (in alfabetiese volgorde) is ruimskoots benut om leksikale inligting vir die bewerkingsvoorstelle hieronder te bekom.

- Collins COBUILD English Dictionary, 1997

- Collins Gem Dictionary of English Spelling, 1994

- Longman Business English Dictionary, 2001

- Pharos New Words / Nuwe Woorde, 1999

- The Reader's Digest Oxford Complete Wordfinder, 1992

- South African Concise Oxford Dictionary, 2002

- Tweetalige Woordeboek/Bilingual Dictionary, 1984

- Verklarende Handwoordeboek van die Afrikaanse Taal, 2000

\section{6. 'n Praktiese model vir 'n vertaalwoordeboek}

Dis belangrik om daarop te let dat woordeboekmaak nie ' $n$ taak is wat deur enkelinge verrig word nie. In 'n werklike situasie sal alle besluite soos dié hieronder aan die oordeel van 'n paneel van kundiges onderworpe wees. Hierbenewens behoort die beginsel van gelyktydige terugvoer (kyk paragraaf 7 hieronder) van meet af aan en deurlopend toegepas te word ten einde die voorgestelde vertaalwoordeboek deur middel van formatiewe evaluering tot stand te bring.

Voorstelle vir die bewerking van ' $n$ aantal lemmas word vervolgens aangebied, vergesel van annotasies wat redes vir besluite uiteensit. Hierdie besluite is deurgaans daarop gemik om die verskillende leksikografiese funksies van 'n vertaalwoordeboek (Crafford 2005: 54-59) te ondersteun.

\section{1 'n Leksikale item met 'n enkele woordsoortelike funksie en slegs een betekenisonderskeiding}

in·cur vt /inkę:/ in·curs, in·cur·ring, in·curred

(become subject to something [unwelcome or unpleasant] as a result of one's actions) jou blootstel aan iets (onaangenaams) of jou iets (onaangenaams) op die hals haal * he behaves badly and incurs the wrath of the community hy gedra hom sleg en haal hom die gramskap / woede van die gemeenskap op die hals.

$\sim$ blame skuld kry; $\sim$ costs / debts / expenses (on)koste / skuld(e) / uitgawes aangaan / mak; $\sim$ danger / risk gevaar loop, jou aan gevaar blootstel; $\sim$ displeasure / wrath jou onguns / onmin / woede op die hals haal; a fine / liability / loss 'n boete / aanspreeklikheid/verlies op die lyf loop; $\sim$ an illness / injury 'n siekte/besering opdoen; a penalty / punishment boete / straf verdien / ontvang.

- SYNONYMS attract, arouse, bring upon or on (oneself), come in for, draw, experience, expose (oneself) to, face, invite, lay (oneself) open to, meet (with), provoke, suffer, sustain, undergo 


\section{Verklarende aantekeninge en rasionalisering van besluite}

\begin{tabular}{|c|c|}
\hline $\mathrm{vt}$ & $\begin{array}{l}\text { Woordsoortaanduiding - die } v \text { staan vir werk- } \\
\text { woord (verb) en die } t \text { dui aan dat dit 'n oorgank- } \\
\text { like (transitive) werkwoord is (in die voortekste- } \\
\text { afdeling moet alle redaksionele afkortings ver- } \\
\text { klaar word). Oorganklikheid of onoorganklik- } \\
\text { heid is soms bepalend vir besluite oor 'n verta- } \\
\text { ling. }\end{array}$ \\
\hline $\begin{array}{l}\text { /Ijke:/ (Die fonetiese alfabet wat } \\
\text { hier gebruik word, is gebaseer op } \\
\text { die simbole van die Internasionale } \\
\text { Fonetiese Alfabet.) }\end{array}$ & $\begin{array}{l}\text { Uitspraak en klem word aangedui. Uitspraak- } \\
\text { leiding is belangrik. } 5 \text { As taalpraktisyns strek ver- } \\
\text { talers se take en pligte wyer as die geskrewe } \\
\text { woord en dit is derhalwe belangrik vir hulle om } \\
\text { die korrekte uitspraak van woorde te ken. }\end{array}$ \\
\hline in·curs, in·cur·ring, in·curred & $\begin{array}{l}\text { Verbuigings van werkwoorde word in die inlei- } \\
\text { dende deel gegee om naslaan te vergemaklik. } \\
\text { Woordafbreking word aangedui omdat dit } \\
\text { belangrik is by die proeflees en taalversorging } \\
\text { van dokumente. }\end{array}$ \\
\hline Geen etimologiese inligting nie & $\begin{array}{l}\text { Dis debatteerbaar of ' } n \text { vertaalwoordeboek eti- } \\
\text { mologiese inligting moet bevat. Sommige verta- } \\
\text { lers meen dit moet wel gegee word, want afge- } \\
\text { sien van taalpraktisyns se belangstelling in } \\
\text { woorde en hul oorsprong, kan etimologiese ken- } \\
\text { nis hulle help om skeppend te vertaal. }{ }^{6} \text { Die } \\
\text { woord palimpses se Griekse etimologie [G. palin } \\
\text { weer + psao skoon vryf] kan die vertaler byvoor- } \\
\text { beeld herinner aan die uitdrukking "om 'n skoon } \\
\text { lei te hê". }\end{array}$ \\
\hline $\begin{array}{l}\text { become subject to (something un- } \\
\text { welcome or unpleasant) as a result } \\
\text { of one's actions }\end{array}$ & $\begin{array}{l}\text { Die betekenisverklaring in die brontaal geskied } \\
\text { d.m.v. 'n kort omskrywing of parafrase. }\end{array}$ \\
\hline $\begin{array}{l}\text { jou blootstel aan iets (onaange- } \\
\text { naams) of jou iets (onaangenaams) } \\
\text { op die hals haal }\end{array}$ & $\begin{array}{l}\text { Die betekenisverklaring vind plaas aan die hand } \\
\text { van ' } n \text { doeltaalparafrase en/of doeltaalsino- } \\
\text { nieme. }\end{array}$ \\
\hline $\begin{array}{l}* \text { he behaves badly and incurs the } \\
\text { wrath of the community }\end{array}$ & $\begin{array}{l}\text { Voorbeeldmateriaal dra sintaktiese en sintagma- } \\
\text { tiese inligting op 'n implisiete wyse oor (dis veral } \\
\text { nuttig by vertaling in T2). Voorbeeldmateriaal } \\
\text { moet verkieslik op korpusnavorsing in parallelle } \\
\text { tekste gegrond wees en nie deur die leksikograaf } \\
\text { self geskep word nie. }{ }^{7}\end{array}$ \\
\hline $\begin{array}{l}\text { hy gedra hom sleg en haal hom die } \\
\text { gramskap / woede van die gemeen- } \\
\text { skap op die hals }\end{array}$ & $\begin{array}{l}\text { Die professionele vertalers in die leksikografiese } \\
\text { span vertaal voorbeeldmateriaal, indien nodig } \\
\text { m.b.v. parallelle tekste. }\end{array}$ \\
\hline
\end{tabular}




\begin{tabular}{|c|c|}
\hline $\begin{array}{l}\text { blame skuld kry; } \sim \text { costs / debts / } \\
\text { expenses (on)koste / skuld(e) / uit- } \\
\text { gawes aangaan / maak; danger / } \\
\text { risk gevaar loop, jou aan gevaar } \\
\text { blootstel; displeasure jou onguns / } \\
\text { onmin op die hals haal; a fine / } \\
\text { liability / loss 'n boete / aanspreek- } \\
\text { likheid / verlies op die lyf loop; } \\
\sim \text { an illness / injury 'n siekte / bese- } \\
\text { ring opdoen; } \sim \text { a penalty / punish- } \\
\text { ment boete / straf verdien / ontvang. }\end{array}$ & $\begin{array}{l}\text { Kollokasies en voorgestelde vertaalekwivalente, } \\
\text { is alfabeties georden. (Ordening op grond van } \\
\text { gebruiksfrekwensie moet op korpusnavorsing } \\
\text { berus.) }\end{array}$ \\
\hline $\begin{array}{l}\text { arouse, attract, bring upon or on } \\
\text { (oneself), come in for, draw, experi- } \\
\text { ence, expose (oneself) to, face, in- } \\
\text { vite, lay (oneself) open to, meet } \\
\text { (with), provoke, suffer, sustain, un- } \\
\text { dergo }\end{array}$ & $\begin{array}{l}\text { Absolute en gedeeltelike sinonieme in die bron- } \\
\text { taal word gegee om die volle betekenispotensiaal } \\
\text { van die lemma incur aan te dui. Waar toepaslik } \\
\text { moet antonieme om dieselfde rede gelys word. } \\
\text { Hulle is alfabeties georden. Ordening op grond } \\
\text { van gebruiksfrekwensie moet op korpusnavor- } \\
\text { sing berus. }\end{array}$ \\
\hline
\end{tabular}

\section{2 'n Leksikale item met meer as een woordsoortelike funksie en een betekenisonderskeiding elk}

en.deav.our vt / Indevə/ (US endeavor) en.deav.ours, en.deav.our.ing, en.deav.oured (try hard [to do or achieve something]) 'n poging aanwend, poog (deftig), probeer, streef, trag (deftig), ywer, of jou beywer (om iets te doen of te bereik) * I will endeavour to arrange a meeting ek sal poog (deftig) om 'n ontmoeting te reël = ek sal 'n ontmoeting probeer reël

- SYNONYMS aim, aspire, attempt, do one's best, essay (formal), exert oneself, have a go or crack or whack or shot at (colloq.), make an effort, strive, struggle, take a stab at (colloq.), try

en·deav•our n /Indeva/ ( $\boldsymbol{U} \boldsymbol{S}$ endeavor)

(act of endeavouring, an earnest and industrious effort, an enterprise - [a formal use]) poging, strewe, stryd, onderneming, waagstuk * It is my constant endeavour to ... Ek streef steeds daarna om ...

- SYNONYMS attempt, effort, enterprise, essay (formal), pains, striving, struggle, undertaking, venture

(cmp) scientific endeavour $n$ wetenskapsbeoefening $(\rightarrow$ scientific $)$

\section{Verklarende aantekeninge en rasionalisering van besluite}

(US endeavor)
Verskeie Engelse woorde het twee of meer spelwyses. By die produksie of kontrolering van geskrewe tekste moet die vertaler hiervan kennis dra. In die voortekste-afdeling sal daar 'n vermelding wees dat wisselvorme gegee word. 


\begin{tabular}{|l|l|}
\hline $\begin{array}{l}\text { Leksikografiese etikette ('formal', } \\
\text { 'colloq.', 'deftig') }\end{array}$ & $\begin{array}{l}\text { Pragmatiese inligting m.b.v. gebruiksetikette } \\
\text { help vertalers met sowel die resepsie as die pro- } \\
\text { duksie van tekste. }\end{array}$ \\
\hline * I will endeavour to ... & $\begin{array}{l}\text { In die voorbeeldsin word twee punte implisiet } \\
\text { tuisgebring: (a) die gebruik van will pleks van } \\
\text { shall om vaste voorneme oor te dra en (b) die feit } \\
\text { dat endeavour met die voorsetsel to verbind. }\end{array}$ \\
\hline cmp ... ( $\rightarrow$ scientific) & $\begin{array}{l}\text { By 'n samestelling (compound) waarvan die eerste } \\
\text { element nie die lemma is nie, verskyn 'n kruis- } \\
\text { verwysing (aangedui m.b.v. 'n pyltjie) na die } \\
\text { plek waar dié element as lemma optree. }\end{array}$ \\
\hline
\end{tabular}

6.3 'n Leksikale item met meer as een woordsoortelike funksie en meervoudige betekenisonderskeidings

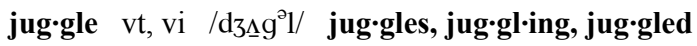

1 (continuously toss in the air and catch a number of objects so as to keep at least one in the air at any time) balle in die lug hou, jongleer (deftig, uitspr. / 3ọlır / ) * to juggle with something met iets jongleer (balle, ens.)

2 (cope with by adroitly balancing [several activities]) baie dinge gelyk doen/hanteer / inpas; behendig / knap werk; oral raakvat

- SYNONYMS manipulate, manoeuvre

3a (rearrange adroitly) goël, goëlkunsies uitvoer, rats herskik, regskommel, toor

- SYNONYMS alter, change, modify, reposition, reset, reshuffle, shift, shuffle, switch, transpose

$\mathbf{3 b}$ (deceive or cheat) bedrieg, fop, kul

- SYNONYMS $\rightarrow$ deceive

3c (misrepresent [facts]) (feite) verdraai, verwring, foutief voorstel, (infml.) dokter, kook - SYNONYMS disguise, distort, falsify, massage, tamper with, rig, fix or doctor or cook or fiddle (colloq.)

(exp) juggle someone out of something iets van iemand afrokkel

jug.gle $\mathrm{n}$

1 (a piece of juggling) baltoertjie, goëltoertjie

- SYNONYMS dexterity, wizardry, sleight of hand

2 (a fraud) bedrieëry, kullery, oëverblindery, skelmstreek

- SYNONYMS deceit, deception, trickery, swindle, sophistry, hocus-pocus, hoax, trick, funny business or rip-off or scam (colloq.)

\section{Verklarende aantekeninge en rasionalisering van besluite}




\begin{tabular}{|l|l|}
\hline $\begin{array}{l}\text { balle in die lug hou, jongleer (def- } \\
\text { tig, uitspr. / 3ojlır /) }\end{array}$ & $\begin{array}{l}\text { Die woord jongleer is in Nederlands taamlik } \\
\text { bekend, maar in Afrikaans is dit weinig ge- } \\
\text { * to juggle with something met } \\
\text { bruiklik. Dit weerspieël 'n toenemende leksikale } \\
\text { gaping. Omdat sommige vertalers d.m.v. terug- } \\
\text { voer op ZaLang ('n elektroniese gespreksgroep } \\
\text { vir vertalers) egter aangedui het dat hulle die } \\
\text { term ken en selfs gebruik, is besluit om dit wel } \\
\text { op te neem, met 'n aanduiding van uitspraak. } \\
\text { (Uitspraak in die doeltaal - m.b.v. dieselfde } \\
\text { fonetiese konvensie as vir die brontaal - hoef } \\
\text { slegs by uitsondering en dan veral by vreemde } \\
\text { woorde gegee te word.) }\end{array}$ \\
\hline 3b SYNONYMS $\rightarrow$ deceive & $\begin{array}{l}\text { Daar is 'n kruisverwysing by 3b omdat dit dupli- } \\
\text { sering sal wees om die sinonieme vir 'deceive' } \\
\text { hier te lys. }\end{array}$ \\
\hline $\begin{array}{l}\text { (Betekenisonderskeidings 1-3c) } \\
\text { 3c verdraai, verwring, foutief voor- } \\
\text { stel, (infml.) dokter, kook }\end{array}$ & $\begin{array}{l}\text { Betekenisonderskeidings word genommer en } \\
\text { apart gehanteer ter wille van duidelikheid. } \\
\text { Ekwivalente word vir elke betekenisonderskei- } \\
\text { ding aangedui. Die leksikale gaping word oor- } \\
\text { brug m.b.v. parafrasering. } \\
\text { Die gebruiksetiket infml. dui informele register } \\
\text { aan. }\end{array}$ \\
\hline $\begin{array}{l}\text { (exp) juggle someone out of some- } \\
\text { thing iets van iemand afrokkel }\end{array}$ & $\begin{array}{l}\text { Vaste uitdrukkings (fixed expressions) word apart } \\
\text { gelys om dit vir die gebruiker makliker te maak } \\
\text { om hulle te vind. }\end{array}$ \\
\hline
\end{tabular}

Afleidings soos juggler, jugglery en juggling act vorm nie deel van die bewerking van die lemma juggle nie, maar sal as aparte lemmas opgeneem word.

\section{4 'n Multileksikale leksikale item met slegs een woordsoortelike funk- sie}

big bang theory $n$

(astronomy) (theory that suggests that the origin of the universe was marked by the rapid expansion of matter from a state of extremely high density and temperature) oerknalteorie, teorie dat ' $n$ ontploffing tot die ontstaan van die heelal gelei het

- SYNONYMS big bang theory = superdense theory

Verklarende aantekeninge en rasionalisering van besluite

\begin{tabular}{|l|l|}
\hline big bang theory & $\begin{array}{l}\text { Die uitspraak word nie aangedui nie, omdat dit } \\
\text { by die lemmas big, bang en theory gedek sal } \\
\text { word. By uitdrukkings in 'n ander taal, soos faux } \\
\text { pas of sine qua non, is uitspraakleiding essensi- } \\
\text { eel. }\end{array}$ \\
\hline (astronomy) & Vaketiket. \\
\hline
\end{tabular}


(theory in astronomy that suggests ...)
Die vertaalwoordeboek vervul 'n kennisfunksie deur onder meer ensiklopediese inligting in die brontaal te verskaf. Dit word in maklik verstaanbare eerder as wetenskaplike taal gegee. ${ }^{8}$

\section{5 'n Multileksikale leksikale item met meer as een woordsoortelike} funksie

fast track $\mathrm{n}$ /fa:stræk/

(a rapid route or method [to reach a goal]) (fig.) kortpad (na bo); dolle vaart (na nêrens) * put something on the fast track die pas van iets versnel

(exp) live on the fast track ' $n$ vinnige pas handhaaf

fast-track $\mathrm{v}$

(accelerate the development or progress of) die pas van iets versnel, iets bespoedig / deurjaag

* his career was fast-tracked in the interest of affirmative action sy loopbaanvordering is bespoedig ter wille van regstellende aksie

Verklarende aantekeninge en rasionalisering van besluite

\begin{tabular}{|l|l|}
\hline fast-track $\mathrm{v}$ & Die gebruiker sal oplet dat die werkwoord met 'n \\
\hline
\end{tabular}
koppelteken gespel word.

\section{Die konsep van gelyktydige terugvoer}

Volgens De Schryver en Prinsloo (2000: 3) is dit "algemeen gebruiklik" dat woordeboekgebruikers aan 'n reeks toetse onderwerp word ten einde hul sukses wat betref die inwin van inligting te meet, m.a.w. te bepaal hoe suksesvol ' $n$ voltooide woordeboek sy funksie vervul. Gewoonlik kan sodanige terugvoer eers in berekening gebring word by ' $n$ volgende of hersiene uitgawe van die gepubliseerde woordeboek. Ideaal gesproke moet teikengebruikers egter terugvoer kan verskaf terwyl die samestelling van die woordeboek nog aan die gang is. Die proses van gelyktydige terugvoer maak hierdie ideaal haalbaar. Dis ' $n$ proses waardeur teikengebruikers se terugvoer verkry word "both from the very start and during the entire compilation process" (De Schryver en Prinsloo 2000: 4). Dit geskied met behulp van 'n reeks bekostigbare, kleinskaalse woordeboekprojekte wat aanvullend van stapel gestuur word en parallel aan die hoofprojek loop. Die kleiner, parallelle projekte het dieselfde basiese struktuur, inhoud en teikengebruikers as die hoofprojek, maar word oor 'n aantal korter periodes afgehandel. Vanaf die oomblik wat die eerste parallelle projek geloods word, word informele en formele terugvoer ingewin en die inligting in die hoofprojek teruggevoer. So word die parallelle projekte deurlopend as eksperimentele instrumente gebruik om verskeie strategieë te beproef en die aanbied 
van inligting in die hoofprojek te verfyn. Die proses kom slegs tot 'n einde wanneer die hoofprojek afgehandel is.

Die gebruik van nuwer tegnologie, soos die internet, kan deesdae 'n dinamiese proses van woordeboekverbetering moontlik maak deurdat dit leksikograwe in staat stel om deurlopend van gebruikers terugvoer te ontvang.

\section{Ten slotte}

De Schryver en Prinsloo (2000: 3) meen dis belangrik dat woordeboeksamestellers nie slegs hul teikengebruikers se behoeftes nie, maar ook hul wense in ag moet neem. Dit maak van teikengebruikers die "bevoorregte kritici" van 'n nuwe woordeboek. Vertalers self moet dus besluit wat hulle in 'n vertaalwoordeboek wil hê en hoe hulle dit wil hê, want volgens die beginsel van gelyktydige terugvoer besluit gebruikers watter data ingesluit of uitgelaat en op watter wyse dit aangebied moet word.

\section{Notas}

1. Die BCD-projek is 'n langtermyn- interuniversitêre projek wat daarop gerig is om 'n tweetalige woordeboek tot stand te bring wat taalgebruik in Kanadese Engels en Kanadese Frans weerspieël (Roberts 1996: 10).

2. In sommige tale bestaan die moontlikheid van 'n meer omvattende toegangsalfabet wat dan implikasies vir die aantal artikelreekse en die ordening daarvan het.

3. Die afkortings BT en DT staan vir "brontaal" en "doeltaal" onderskeidelik, terwyl uitdr. "vaste uitdrukkings" en ss "samestellings" aandui. Sowel die brontaal as die doeltaal kan as metataal gebruik word, afhangende van die onmiddellike taalomgewing.

4. Die gebruiker sal in die voortekste-afdeling ingelig word dat sowel absolute as gedeeltelike sinonieme alfabeties gelys word en dat die sinonieme mekaar nie oral kan vervang nie.

5. Roberts (1996: 22) stem nie saam nie. Sy meen uitspraak "is the aspect of form that is least important for translators, who have to know how to write correctly but not necessarily how to pronounce correctly".

6. Roberts (1996: 22-23) meen egter etimologiese inligting kan vertalers mislei en selfs aanleiding gee tot die verskynsel van vals vriende. Volgens haar kan sommige woorde in 'n vertaler se twee werkstale dieselfde oorsprong hê en daarom vormlik ooreenstem, maar kon hulle mettertyd 'n effense verskil in betekenis ontwikkel het.

7. Die internet maak voorbeeldmateriaal in woordeboeke toenemend oorbodig vir vertalers wat toegang het tot die wêreldwye web en daar kan opsoek hoe woorde in bepaalde kontekste optree.

8. De Beaugrande (2003: 3) meen dat die taak om definisies te verskaf in die verlede te dikwels oorgelaat is aan spesialiste in verskillende vakrigtings, wat dan met definisies "no less obscure than the expression itself" vorendag gekom het. Die gebruik van korpusse kan verseker dat die betekenisse wat gegee word werklik in gewone tekste voorkom, wat nie noodwendig is hoe ' $n$ spesialis dit sou stel nie. 


\section{Bronnelys}

\section{Woordeboeke}

Bilingual Canadian Dictionary: Sample Entries. 2004. http://www.dico.uottawa.ca/entries-en.htm [2 November 2004].

Bosman, D.B., I.W. van der Merwe en L.W. Hiemstra. 1984. Tweetalige Woordeboek/Bilingual Dictionary. Kaapstad: Tafelberg.

Collins Gem Dictionary of English Spelling. 1994. Londen: HarperCollins.

Du Plessis, Madaleine. 1999. New Words and Previously Overlooked Ones/Nuwe woorde en oues wat in die slag gebly het. English-Afrikaans. Kaapstad: Pharos.

Kavanagh, K., D. Mantzel, T. van Niekerk, J. Wolvaardt en M. Wright. 2002. South African Concise Oxford Dictionary. Kaapstad: Oxford University Press.

Longman Business English Dictionary. 2001. Harlow: Pearson Education.

Odendal, F.F., P.C. Schoonees, C.J. Swanepoel, S.J. du Toit en C.M. Booysen. 2000³. Verklarende Handwoordeboek van die Afrikaanse Taal. Johannesburg: Perskor.

Sinclair, J., G. Fox en S. Bullon (Reds.). 1997. Collins COBUILD English Dictionary. Londen: HarperCollins.

Tulloch, Sara. 1993. The Reader's Digest Oxford Complete Wordfinder. Londen: The Reader's Digest Association.

\section{Ander}

Biber, Douglas, Susan Conrad en Randi Reppen. 1998. Corpus Linguistics: Investigating Language Structure and Use. Cambridge: Cambridge University Press.

Crafford, M.F. 2005. Vertalers en hul bronne: Die behoefte aan ' $n$ vertaalwoordeboek met Engels en Afrikaans as behandelde taalpaar. Ongepubliseerde M.Phil.-skripsie. Stellenbosch: Universiteit van Stellenbosch.

De Beaugrande, Robert. 2003. Function and Form of Reference Works: Setting a Record Straight for J. McH. Sinclair and the COBUILD. http://beaugrande.com/SinclairCarstensen.htm [27 Februarie 2003].

De Schryver, Gilles-Maurice en D.J. Prinsloo. 2000. The Concept of 'Simultaneous Feedback': Towards a New Methodology for Compiling Dictionaries. Lexikos 10: 1-31.

Feinauer, Ilse. 2001. Language Contact between Afrikaans and English Leads to Conceptual Change in Afrikaans. Thelen, M. en B. Lewandowska-Tomasczczyk (Reds.). 2001. Translation and Meaning Part 5: 163-171. Maastricht: Hogeschool Zuyd, Maastricht School of International Communication.

Gouws, Rufus H. 2001. Lexicographic Training: Approaches and Topics. Emejulu, J. Duplessis (Red.). 2001. Éléments de lexicographie gabonaise, Tome I: 58-94. New York: Jimacs-Hillman.

Keyser, Helane. 2003. Ondersoek na 'n model vir die opleiding van leksikograwe vir verklarende woordeboeke. Ongepubliseerde M.Phil.-skripsie. Stellenbosch: Universiteit van Stellenbosch.

Kussmaul, Paul. 1995. Training the Translator. Amsterdam/Philadelphia: John Benjamins.

Louw, Phillip A. 1999. Access Structures in a Standard Translation Dictionary. Lexikos 9: 108-118. 
Mossop, Brian. 1998. The Workplace Procedures of Professional Translators. Chesterman, A., N. Gallardo San Salvador en Y. Gambier (Reds.). 1998. Translation in Context: Selected Contributions from the EST Congress, Granada 1998: 39-48. Amsterdam: John Benjamins.

Neubert, Albrecht en Gregory M. Shreve. 1992. Translation as Text. Kent, Ohio: Kent State University.

Presas, Marisa. 2000. Bilingual Competence and Translation Competence. Schäffner, C. en B. Adab (Reds.). 2000. Developing Translation Competence: 19-31. Amsterdam/Philadelphia: John Benjamins.

Roberts, Roda P. 1990. Translation and the Bilingual Dictionary. Meta 25(1): 74-82.

Roberts, Roda P. 1992a. Organization of Information in a Bilingual Dictionary Entry. EURALEX '90 Proceedings. IV International Congress: 219-231. Barcelona: Biblograf in samewerking met die Kommissie vir Europese Gemeenskappe.

Roberts, Roda P. 1992b. Methods of Bilingual Dictionary-making: The Canadian Experience. Hyldgaard-Jensen, K. en A. Zettersten (Reds.). 1992. Symposium on Lexicography V: 91-116. Tübingen: Max Niemeyer.

Roberts, Roda P. 1996. Dictionaries, Dictionary-making and Translation. Nistal, P.F. and J.M.B. Gozalo (Reds.). 1996. A Spectrum of Translation Studies: 9-35. Valladolid: Universidad de Valladolid, Servicio de Apoyo a la Ensenanza.

Simpson, John. 2002. The Revolution of English Lexicography. Dictionaries: The Journal of the Dictionary Society of North America 23: 1-15.

Tarp, Sven. 2002. Translation Dictionaries and Bilingual Dictionaries: Two Different Concepts. Journal of Translation Studies 7: 59-84.

Tarp, Sven. 2004. Reflections on Dictionaries Designed to Assist Users with Text Production in a Foreign Language. Lexikos 14: 299-325. 